Reconnaissance Study of the Major and Trace Element Content of Bauxite Deposits in the Arkansas Bauxite Region, Saline and Pulaski Counties, Central Arkansas

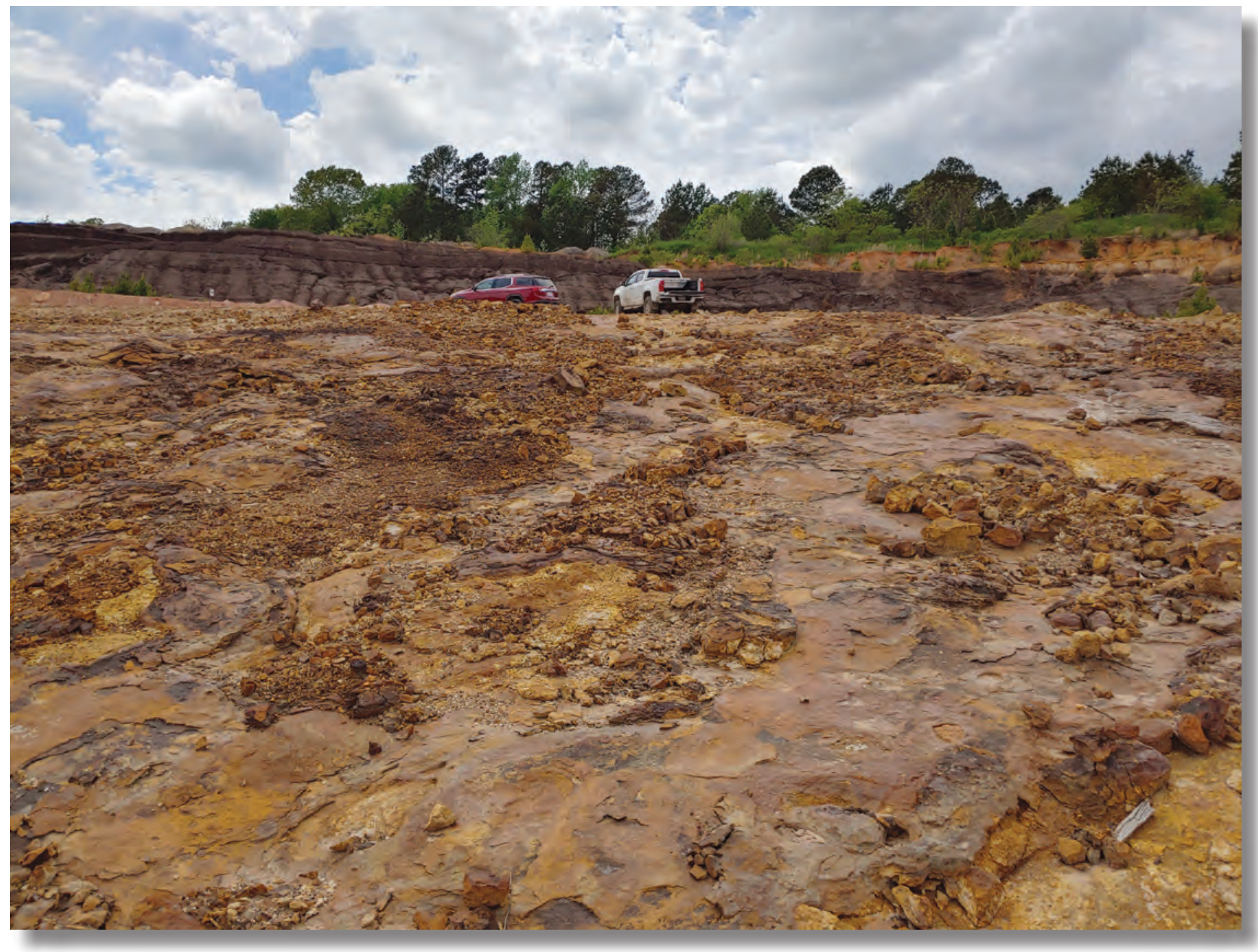

Open-File Report 2021-1073 
Cover. Apron of bauxite layers exposed at the base of a former bauxite mine in central Arkansas. 


\section{Reconnaissance Study of the Major and Trace Element Content of Bauxite Deposits in the Arkansas Bauxite Region, Saline and Pulaski Counties, Central Arkansas}

By Bradley S. Van Gosen and LaDonna M. Choate

Open-File Report 2021-1073 


\section{U.S. Geological Survey, Reston, Virginia: 2021}

For more information on the USGS - the Federal source for science about the Earth, its natural and living resources, natural hazards, and the environment—visit https://www.usgs.gov or call 1-888-ASK-USGS.

For an overview of USGS information products, including maps, imagery, and publications, visit https://store.usgs.gov/.

Any use of trade, firm, or product names is for descriptive purposes only and does not imply endorsement by the U.S. Government.

Although this information product, for the most part, is in the public domain, it also may contain copyrighted materials as noted in the text. Permission to reproduce copyrighted items must be secured from the copyright owner.

Suggested citation:

Van Gosen, B.S., and Choate, L.M., 2021, Reconnaissance study of the major and trace element content of bauxite deposits in the Arkansas bauxite region, Saline and Pulaski Counties, central Arkansas: U.S. Geological Survey Open-File Report 2021-1073, 18 p., https://doi.org/10.3133/ofr20211073.

Associated data for this publication:

Van Gosen, B.S., and Choate, L.M., 2019, Geochemical analyses of bauxite and associated rocks from the Arkansas bauxite region, central Arkansas: U.S. Geological Survey data release, accessed May 21, 2021, at https://doi.org/10.5066/P999FSXM.

ISSN 2331-1258 (online) 


\section{Acknowledgments}

The authors thank Granite Mountain Quarries for granting us permission to sample within their mined properties. We appreciate the site tours and information provided by their geologists. 



\section{Contents}

Acknowledgments ……...................................................................................................................

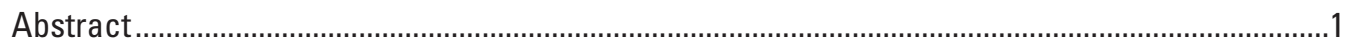

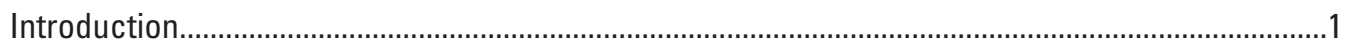

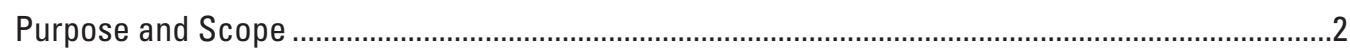

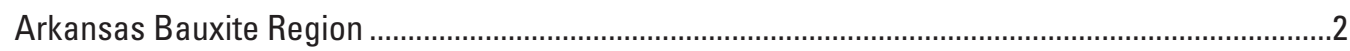

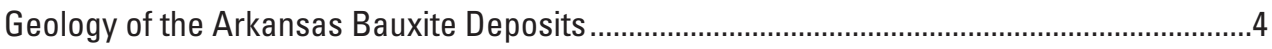

Bauxite Mineralogy and Textures ..............................................................................................

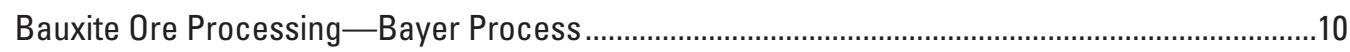

Element Concentrations Relative to Average Upper Crust Abundance ..........................................12

Concentrations and Partitioning of Gallium, Niobium, Scandium, and Rare Earth Elements

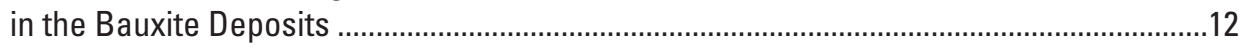

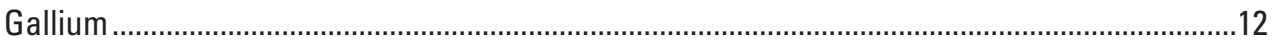

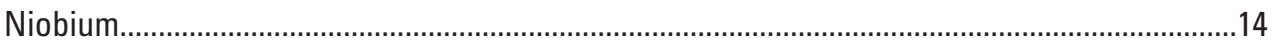

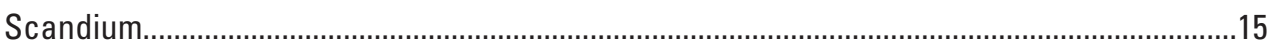

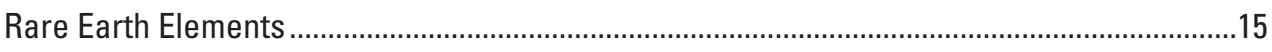

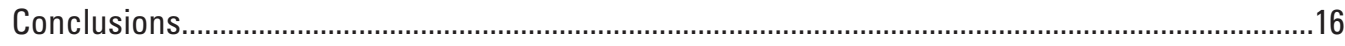

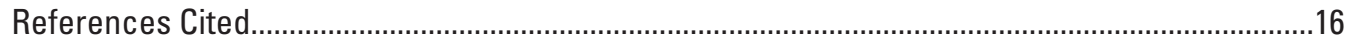

\section{Figures}

1. Index map of the Arkansas bauxite region showing former bauxite mine sites and locations of samples collected and analyzed for this study........................................

2. Generalized stratigraphy of the Arkansas bauxite district...................................................

3. Generalized geologic map of the Arkansas bauxite district and surrounding area..........6

4. Image showing specimen of nepheline syenite from the Granite Mountain pluton .........8

5. Schematic section showing the general stratigraphic setting of the bauxite deposit types in the Arkansas bauxite region........................................................................

6. Photograph showing apron of bauxite layers exposed at the base of a former bauxite mine in central Arkansas ................................................................................10

7. Photograph showing outcrop of pisolitic bauxite, the most common variety of bauxite in the central Arkansas region............................................................................11

8. Photograph showing slabbed specimen of pisolitic bauxite ..........................................12

9. Graph showing average concentrations of elements in the sample types collected in this study in comparison to reported average concentrations in the Earth's upper crust

10. Graph showing average concentrations of the rare earth elements in the sample types collected in this study in comparison to their reported average concentrations in the Earth's upper crust

\section{Table}

1. Average concentrations of selected elements in rock samples collected by this study in the Arkansas bauxite region. 


\section{Conversion Factors}

U.S. customary units to International System of Units

\begin{tabular}{|c|c|c|}
\hline Multiply & By & To obtain \\
\hline \multicolumn{3}{|c|}{ Length } \\
\hline inch (in.) & 2.54 & centimeter $(\mathrm{cm})$ \\
\hline foot $(\mathrm{ft})$ & 0.3048 & meter $(\mathrm{m})$ \\
\hline mile (mi) & 1.609 & kilometer $(\mathrm{km})$ \\
\hline \multicolumn{3}{|c|}{ Area } \\
\hline square mile $\left(\mathrm{mi}^{2}\right)$ & 2.590 & square kilometer $\left(\mathrm{km}^{2}\right)$ \\
\hline \multicolumn{3}{|c|}{$\begin{array}{l}\left.\text { Temperature in degrees Celsius }\left({ }^{\circ} \mathrm{C}\right) \text { may be converted to degrees Fahrenheit ( }{ }^{\circ} \mathrm{F}\right) \text { as follows } \\
\qquad{ }^{\circ} \mathrm{F}=\left(1.8 \times{ }^{\circ} \mathrm{C}\right)+32 .\end{array}$} \\
\hline
\end{tabular}

\section{Abbreviations}

$\begin{array}{ll}\text { atm } & \text { The standard atmosphere (symbol: atm) is a unit of pressure roughly equivalent } \\ & \text { to the mean sea-level atmospheric pressure on Earth. The Earth's atmospheric } \\ \text { pressure at sea level is approximately } 1 \text { atm. }\end{array}$




\title{
Reconnaissance Study of the Major and Trace Element Content of Bauxite Deposits in the Arkansas Bauxite Region, Saline and Pulaski Counties, Central Arkansas
}

\author{
By Bradley S. Van Gosen and LaDonna M. Choate
}

\section{Abstract}

The Arkansas bauxite district, which comprises about 275 square miles (710 square kilometers) of central Arkansas, produced an order of magnitude more bauxite and alumina than the other bauxite districts in the United States combined. Bauxite was mined in the region continuously from 1898 to 1982 . These bauxites are laterite deposits, formed from intensive in-place weathering of the exposed surface of the Granite Mountain pluton, a Late Cretaceous batholith composed mainly of nepheline syenite and lesser amounts of syenite. Nepheline syenite was the aluminum source for the bauxite and clay deposits that blanket the pluton. The early Eocene continental sedimentary rocks that contain and overlie the bauxite deposits indicate that central Arkansas had a warm tropical environment during bauxite formation.

Bauxite ores are the principal sources of aluminum. Some of the global bauxite deposits have been found to contain co-occurring metals that have essential applications in modern technologies. For example, bauxite is the largest global source of gallium $(\mathrm{Ga})$, used in semiconductors, which is recovered as a byproduct of processing bauxite to recover alumina. Other critical metal commodities within some bauxites that reportedly have potential for byproduct recovery include niobium $(\mathrm{Nb})$, scandium ( $\mathrm{Sc}$ ), and rare earth elements (REEs). Currently (2021), the United States is wholly dependent on imports for its supplies of bauxite for processing to produce alumina. The United States is also dependent on foreign sources of gallium, niobium, and scandium, as well for most of its domestic requirements of REEs.

For these reasons, samples were collected from Arkansas bauxite deposits, associated clays, mill residue wastes (respectively referred to as red muds and black sands), and the parent nepheline syenite to determine their elemental content, with a particular focus on gallium, niobium, scandium, and REEs. Each sample was analyzed for 60 elements; these data and the methods used are published as a U.S. Geological Survey data release.

The results indicate that, of the critical metals in bauxites, gallium is a potential byproduct from the central Arkansas bauxite deposits. The highest gallium concentrations occur in the raw bauxite ore, with an average concentration of 76 parts per million (ppm). Gallium partitions with alumina (the product) rather than into mine waste residues. Results indicate an average niobium content of $662 \mathrm{ppm}$ in the Arkansas bauxite ores. Niobium progressively increases in concentration from parent syenite (247 ppm) to clays (315 ppm) and further from bauxite (662 ppm) to processed residues (1,075 ppm). Low concentrations of scandium were found in all samples, averaging $10 \mathrm{ppm}$ or less in the parent rock (syenite), bauxite, clays, and processing residues. Modest concentrations of the light and heavy REEs were found in samples of bauxite ores, bauxitic clays and interbedded clays, syenite, and the residues of ore. The highest REE values were found in processed residues, with average concentrations of $613 \mathrm{ppm}$ total light REEs and $130 \mathrm{ppm}$ total heavy REEs. These concentrations suggest that additional processing to recover REEs is unlikely to be economic in the foreseeable future.

\section{Introduction}

This study is part of a larger effort by the U.S. Geological Survey (USGS) to advance understanding of the nation's critical mineral resources. The Systems Approach to Critical Minerals Inventory, Research, and Assessment project is designed to characterize mineral deposits hosting critical minerals, trace their enrichment from source to trap, and develop techniques for resource assessments. Based on USGS studies, a list of 35 mineral commodities were designated as critical based on their important applications in current technologies combined with heavy reliance on foreign sources for their supply (Nassar and others, 2015; McCullough and Nassar, 2017; Fortier and others, 2018). Aluminum (Al), gallium (Ga), niobium $(\mathrm{Nb})$, scandium (Sc), and rare earth elements (REEs) are included in the list of critical commodities, mainly due to significant dependence on foreign supply for these metals.

This report summarizes a reconnaissance study of the major and trace element content of bauxite deposits and genetically related rock types in the Arkansas bauxite district of central Arkansas. The rock samples were collected by 
USGS personnel in April 2019. Geochemical analyses of the samples with descriptions of the methods used were released as a USGS data release (Van Gosen and Choate, 2019).

Aluminum is manufactured from alumina which, in turn, is derived from bauxite. Other co-occurring elements of potential interest as byproducts in bauxites are gallium, niobium, scandium, and REEs, which each have important applications in modern technologies. These metals have been reported to occur in elevated amounts within the bauxite deposits of central Arkansas, as well as within bauxite deposits in several other countries. Bauxite is the largest global source of gallium, recovered as a byproduct of the processing of bauxite to recover alumina; zinc sulfide ores are the second largest source of gallium (Gibson and Hayes, 2011; Frenzel and others, 2016). This study of the Arkansas bauxite deposits analyzed the major and trace element contents of bauxite samples, residues from bauxite processing, and clays associated with bauxite formation. Each sample was analyzed for 60 elements; these data are available for download in spreadsheet format as a USGS data release (Van Gosen and Choate, 2019). This study had particular interest in the concentrations of gallium, niobium, scandium, and REEs in the bauxite ores and mill residues to evaluate their potential as byproducts of bauxite processing.

In 2017 and recent years, there have been five primary aluminum smelters in the United States. The smelters have been dependent on imported bauxite as their raw material because bauxite is not currently mined in the United States. Sources of imported bauxite from 2013 to 2016 were 46 percent from Jamaica, 30 percent from Brazil, 21 percent from Guinea, 2 percent from Guyana, and 1 percent from other sources (Bray, 2018). Due to this foreign dependence, aluminum was designated as a critical element that requires investigation to identify and characterize domestic deposits (Fortier and others, 2018). Likewise, gallium and scandium, also deemed critical, are not currently mined or recovered in the United States (Gambogi, 2020b; Jaskula, 2020).

As of 2021, REEs are only produced from one mine in the United States - the Mountain Pass Mine in southeastern California - which mines a large intrusion of carbonatite that is highly enriched in the light REEs. The primary ore mineral in this carbonatite ore body is bastnäsite, a REE-fluorocarbonate mineral (Verplanck and others, 2014). A bastnäsite concentrate is produced at the mine site and is then shipped to China for its final processing and for separation of the individual REEs. During the 20th century, the United States has had at least 90 percent dependence on foreign sources for REE production and has had an even greater dependence on Chinese imports for processed rare earth compounds and metals (Gambogi, 2020a).

\section{Purpose and Scope}

In several countries, waste products (referred to as red mud) derived from the processing of bauxite to extract alumina have been evaluated and purported as potential sources of byproduct gallium, niobium, scandium, REEs, and other metals (Liu and Naidu, 2014; Borra and others, 2015; Liu and Li, 2015; Reid and others, 2017). This study focused on the bauxite deposits of Arkansas to examine the concentrations of co-occurring critical minerals in these deposits. This report summarizes the analytical results of 53 samples collected from the Arkansas bauxite region (fig. 1), including bauxite ( $\mathrm{n}=18)$, residue from the processing of bauxite $(n=4)$, clays stratigraphically beneath and interbedded with the bauxite $(n=15)$, and syenite $(n=16)$. Syenite was sampled because the Arkansas bauxite formed from the extensive in-place (in situ) weathering of syenite intrusions in the region. This suite of samples provides a comparison of the alumina source rock (syenite), the alteration products formed by weathering (clays and bauxite), and residual wastes generated by bauxite processing. The bauxite and clay samples were collected as grab samples from exposures in former open-pit bauxite mines, as well as subsurface samples of drill cuttings. The syenite samples were collected at active syenite aggregate quarries operated by Granite Mountain Quarries. The company generously provided access to the sample sites and shared valuable insights on the local geology.

\section{Arkansas Bauxite Region}

The Arkansas bauxite region is located near the center of Arkansas and comprises two bauxite mining districts with past production: (1) a district of former mines in Pulaski County about 4 kilometers $(\mathrm{km})$ southeast and $8 \mathrm{~km}$ southwest of Little Rock, respectively, and (2) a district of greater historical production and some recent activity in Saline County, centered about $27 \mathrm{~km}$ southwest of Little Rock and $8 \mathrm{~km}$ east of Benton (fig. 1). The Arkansas bauxite region encompasses about 275 square miles (710 square kilometers $\left.\left[\mathrm{km}^{2}\right]\right)$. The inferred bauxite resources that remain in the Arkansas districts greatly exceed those in the other bauxite districts within the United States. These districts are in Alabama, Georgia, Mississippi, Tennessee, and Virginia (Patterson, 1967). The Arkansas bauxite district produced an order of magnitude more bauxite and alumina than all other U.S. districts combined (Patterson, 1967).

Bauxite was mined in the Little Rock region continuously for alumina from 1898 to 1982 (Bramlette, 1936; Malamphy and others, 1948a; Arkansas Geological Survey, 2019).

Production amounts varied significantly during those years. Most of the bauxite mining was by open-pit methods; some underground mining began in 1927 and occurred into the period of World War II (Malamphy and others, 1948a). The high point of bauxite production occurred in 1943, with the production of more than 6 million long tons (6.1 million metric tons) in 


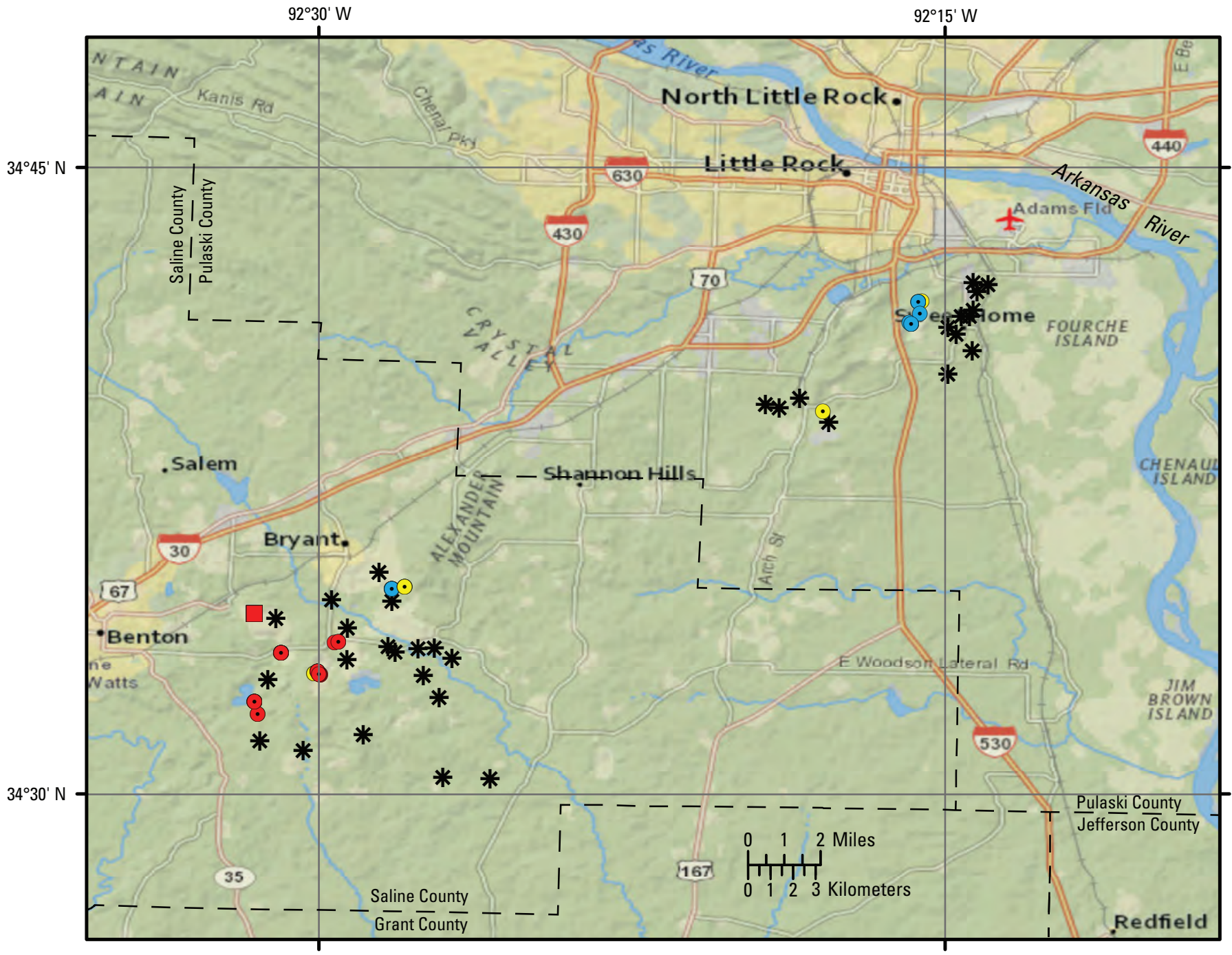

\section{Explanation}

* Former bauxite mine

- Bauxite sample site (at a former bauxite mine)

Bauxite residue sample site

- Syenite sample site

$\odot$ Clay sample site

Figure 1. Arkansas bauxite region showing former bauxite mine sites and locations of samples collected and analyzed for this study. Bauxite samples were collected at former bauxite mines. Sample locations and geochemical analyses are provided in Van Gosen and Choate (2019). 
response to a government mandate to supply aluminum for airplanes during World War II (Malamphy and others, 1948a; Howard and others, 1997). Including the mining districts in both Pulaski and Saline Counties, Gordon and others (1958, their plate 1) identified 129 bauxite mines in the Little Rock region.

The U.S. Bureau of Mines conducted an exploratory drilling program to evaluate the Arkansas bauxite deposits during World War II as part of the Second Supplemental National Defense Act of 1941. The results and drill logs from this drilling program are described in Malamphy and others (1948a, 1948b). The authors reported that "77 bauxite deposits were discovered and/or investigated by drilling at closely spaced intervals" (Malamphy and others, 1948a, p. 62). Earlier, in 1934, the USGS drilled 55 test holes with an average depth of 167 feet (ft) (51 meters [m]) into bauxite deposits of the district, described by Bramlette (1936).

The mining of bauxite for the purpose of aluminum metal production ended in the region in 1990 (Howard and others, 1997). Since then, much smaller tonnages of bauxite have been mined for use in chemicals, abrasives, and proppants. Proppants are rounded pellets used to induce hydraulic fracturing ("fracking") and (or) to maintain open fractures produced by fracturing.

\section{Geology of the Arkansas Bauxite Deposits}

The bauxite deposits of the Arkansas bauxite region were discovered in 1887 by John Branner while he was the State Geologist of Arkansas, during the first month of existence of the Geological Survey of Arkansas. His papers provided the first descriptions and speculations on the origins of the Arkansas deposits (Branner, 1891, 1897), which included models of deposition near sea shorelines and (or) associations with hot springs. The early hypotheses considered to explain the origins of these deposits were further discussed by Mead (1915). Explanations of the processes that formed these bauxites have changed significantly since the early papers. As a result of the discovery of significant bauxite resources in central Arkansas, detailed studies and reports were undertaken by Hayes (1901) for the USGS and by Bramlette (1936) for the Arkansas Geology Survey. A subsequent study by Gordon and others (1958) produced an extensive report that provides in-depth descriptions of the geology and bauxite deposits of the region. The reader is referred to those reports for their descriptions of the geology of the bauxite region and detailed characteristics of the deposits, which are only briefly summarized herein.

The bauxite deposits of central Arkansas formed from the intensive lateritic weathering of the Granite Mountain pluton, part of a Late Cretaceous batholith composed mainly of nepheline syenite and lesser amounts of syenite (figs. 2 and 3). The Granite Mountain pluton has been dated at about 90 million years (Ma) by the ${ }^{40} \mathrm{Ar} /{ }^{39} \mathrm{Ar}$ method, indicating that it is the youngest of the Late Cretaceous alkaline igneous complexes that trend from southwestern to central Arkansas (Baksi, 1997).
Nepheline syenite (fig. 4) was the source for the bauxite and alumina clay deposits that covered the pluton. Gordon and others $\left(1958\right.$, p. 99) suggested that the high alumina $\left(\mathrm{Al}_{2} \mathrm{O}_{3}\right)$ and relatively low silica $\left(\mathrm{SiO}_{2}\right)$ content of the nepheline syenite (about 20 weight percent $\mathrm{Al}_{2} \mathrm{O}_{3}$ and 57 weight percent $\mathrm{SiO}_{2}$ in our samples, table 1) contributed to its "susceptibility to deep weathering that permits free percolation and thorough leaching by ground waters, and its topographic relief in hills that stood high enough above the flatter surface *** to ensure free ground-water movement." They noted that subsurface mapping of the bauxite deposits in the region showed that the bauxites cluster on and around topographic highs, which were hills on the exposed surface of the nepheline syenite pluton during bauxite formation.

The early Eocene continental sedimentary rocks that contain and overlie the bauxite deposits (fig. 2) have characteristics that indicate a tropical environment existed in central Arkansas during the formation of the bauxites. A warm (or hot), wet tropical climate during the early Eocene (Gordon and others, 1958) generated lateritic weathering upon the surface of the nepheline syenite pluton where it was exposed during this period. Weathering that was intense and presumably prolonged formed the clay and bauxite layers that form a discontinuous carapace on the pluton. The clay and bauxite deposits initially formed in situ on an erosional surface at the base of the early Eocene Berger Formation of the Wilcox Group. The clay and bauxite strata were subsequently overlain by terrestrial sedimentary rocks of clay and sand interbedded with lignite, carbonaceous shale and clay, and layers of siderite (iron (II) carbonate) (figs. 2, 5, and 6).

Gordon and others (1958) recognized that the bauxite deposits of the Arkansas bauxite region occur in four general types of deposits, defined according to stratigraphic setting (fig. 5):

- Residual deposits that lie directly upon nepheline syenite;

- Colluvial deposits at the base of the Berger Formation;

- Stratified deposits within the Berger Formation; and

- Conglomeratic deposits at the base of the overlying early Eocene Saline Formation.

The samples of bauxite collected by this study in former bauxite mines were examples of Type 1 and Type 2 deposits.

The bauxite deposits in the district range considerably in thickness and areal extent. Their thickness and distribution were apparently controlled by the topography of the pluton on which the bauxite formed. Bauxite layers range from thin veneers a few millimeters thick to much thicker blanket deposits with a maximum observed thickness of $18 \mathrm{~m}$ ( $60 \mathrm{ft}$; Gordon and others, 1958). Large bauxite deposits can extend for as much as approximately a square mile $\left(2.6 \mathrm{~km}^{2}\right)$, and "in most of the large deposits, the thickness reaches a maximum of $35 \mathrm{ft}$ [about $11 \mathrm{~m}$ ] and averages about 14 feet [4 m]" (Gordon and others, 1958, p. 99). 


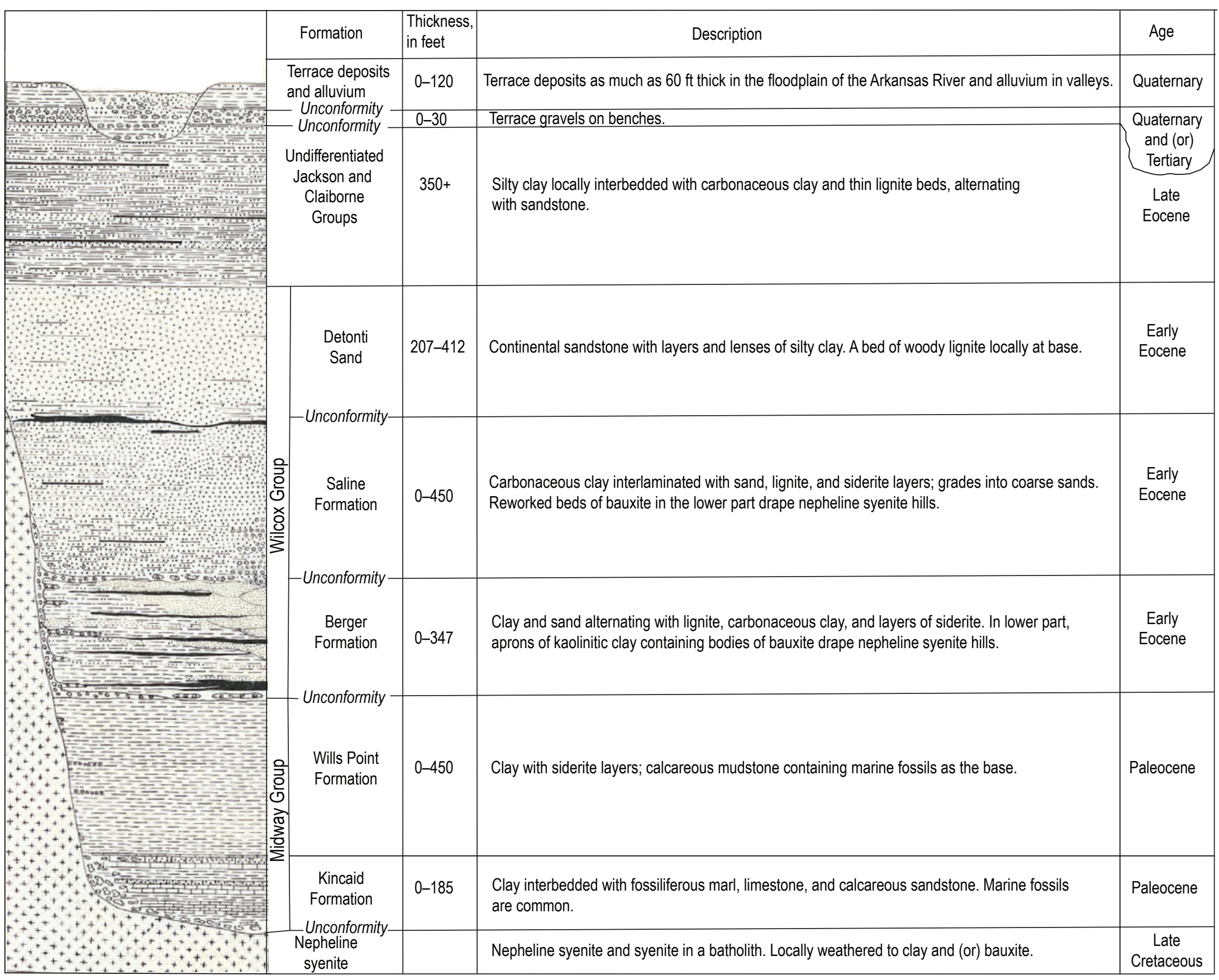

Figure 2. Generalized stratigraphy of the Arkansas bauxite district. Adapted from Gordon and others (1958). 


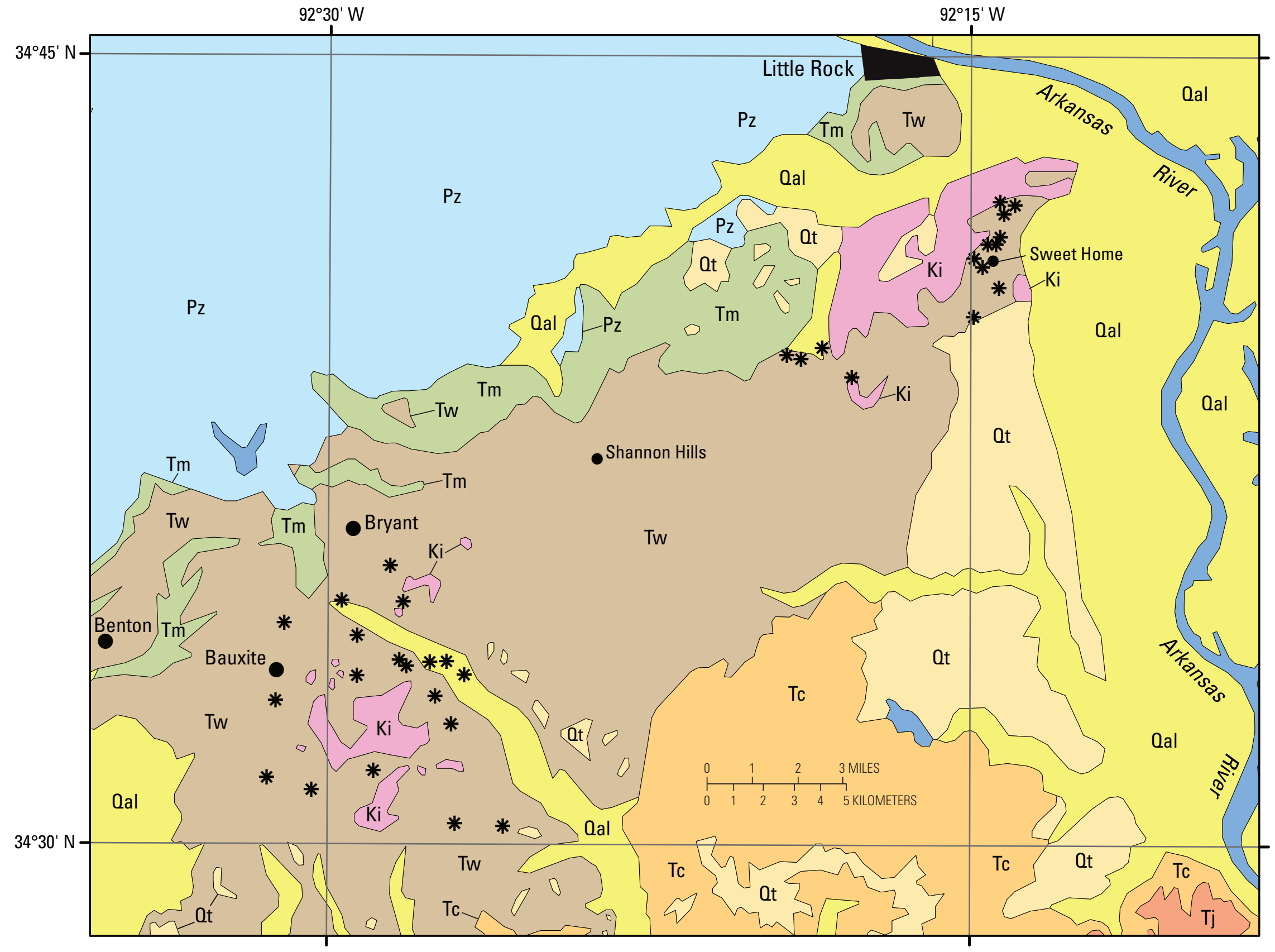

Figure 3. Generalized geologic map of the Arkansas bauxite district and surrounding area. Adapted from Horton (2017). Explanation for generalized geology map of the Arkansas bauxite district and surrounding area. Lithologic descriptions of the geologic units are shown in figure 2. 


\section{Explanation}

Water

\section{Oal}

Qt

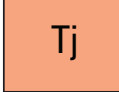

\section{Tc}

\section{Tw}

$\mathrm{Tm}$

\section{$\mathrm{Ki}$}

Nepheline syenite (Late Cretaceous)

\section{$\mathrm{Pz}$}

\author{
Paleozoic sedimentary rocks (Ordovician, \\ Devonian, Misssissippian, and \\ Pennsylvanian)
}

* Former bauxite mine

City

Figure 3. Generalized geologic map of the Arkansas bauxite district and surrounding area. Adapted from Horton (2017). Explanation for generalized geology map of the Arkansas bauxite district and surrounding area. Lithologic descriptions of the geologic units are shown in figure 2.-Continued

\section{Bauxite Mineralogy and Textures (Summarized from Gordon and Others, 1958)}

The primary ore mineral in the Arkansas bauxite deposits is gibbsite, an aluminum hydroxide $\left[\mathrm{Al}(\mathrm{OH})_{3}\right.$, also written as $\left.\mathrm{Al}_{2} \mathrm{O}_{3} \cdot \mathrm{H}_{2} \mathrm{O}\right]$. The gibbsite is mainly cryptocrystalline and consequently appears amorphous, even under high magnification. It is intimately intergrown with finely disseminated iron-oxide minerals. The gibbsite and iron oxides are accompanied by kaolinite $\left.\left[\mathrm{Al}_{2} \mathrm{Si}_{2} \mathrm{O}_{5}(\mathrm{OH})_{4}\right]\right)$. Bauxite and kaolinite layers intergrade, varying from nearly pure gibbsite to nearly pure layers of kaolinite clay; kaolinite also occurs in cavities and veinlets that cut through the bauxite. The primary iron mineral in the bauxite is siderite $\left(\mathrm{FeCO}_{3}\right)$, which is irregularly distributed.

Minor mineral constituents of the Arkansas bauxites are hematite, goethite, magnetite, and zircon, and some deposits contain accessory chlorite. Ilmenite $\left(\mathrm{FeTiO}_{3}\right)$ is a minor accessory mineral in the nepheline syenite and became a residual mineral in the bauxite and clays, where it is often altered to anatase $\left(\mathrm{TiO}_{2}\right)$, thereby liberating $\mathrm{Fe}^{2+}$ for the formation of siderite. The ilmenite in the Arkansas bauxites is known to contain niobium, representing a potential source of niobium that could be obtained from the recovery of ilmenite during the processing of the bauxite.

The Arkansas bauxites display a few different textures, described by Gordon and others (1958) to include the following:

1. A "granitic texture" found directly on the weathered surface of the pluton and which partly preserves the original phaneritic texture of the nepheline syenite;

2. A pisolitic variety composed of spherical nodular concretions, which is the most common bauxite variety in the Arkansas deposits (figs. 7 and 8);

3. Massive or clay-like bauxite; and

4. A vermicular appearance, with irregular tube-like bodies of iron oxides, which resemble worm bores.

The distinct pisolitic form of bauxite consists of numerous concretions composed of cryptocrystalline gibbsite and lesser amounts of kaolinite in a matrix of clays (primarily kaolinite) and minor amounts of quartz. Gordon and others (1958) suggested that concretions less than 2 millimeters (mm) in diameter are called oolites, and those greater than $2 \mathrm{~mm}$ across are to be called pisolites. Examples of pisolitic bauxite are shown in figures 7 and 8 . Most of the bauxite samples collected in this study are the pisolitic variety. 


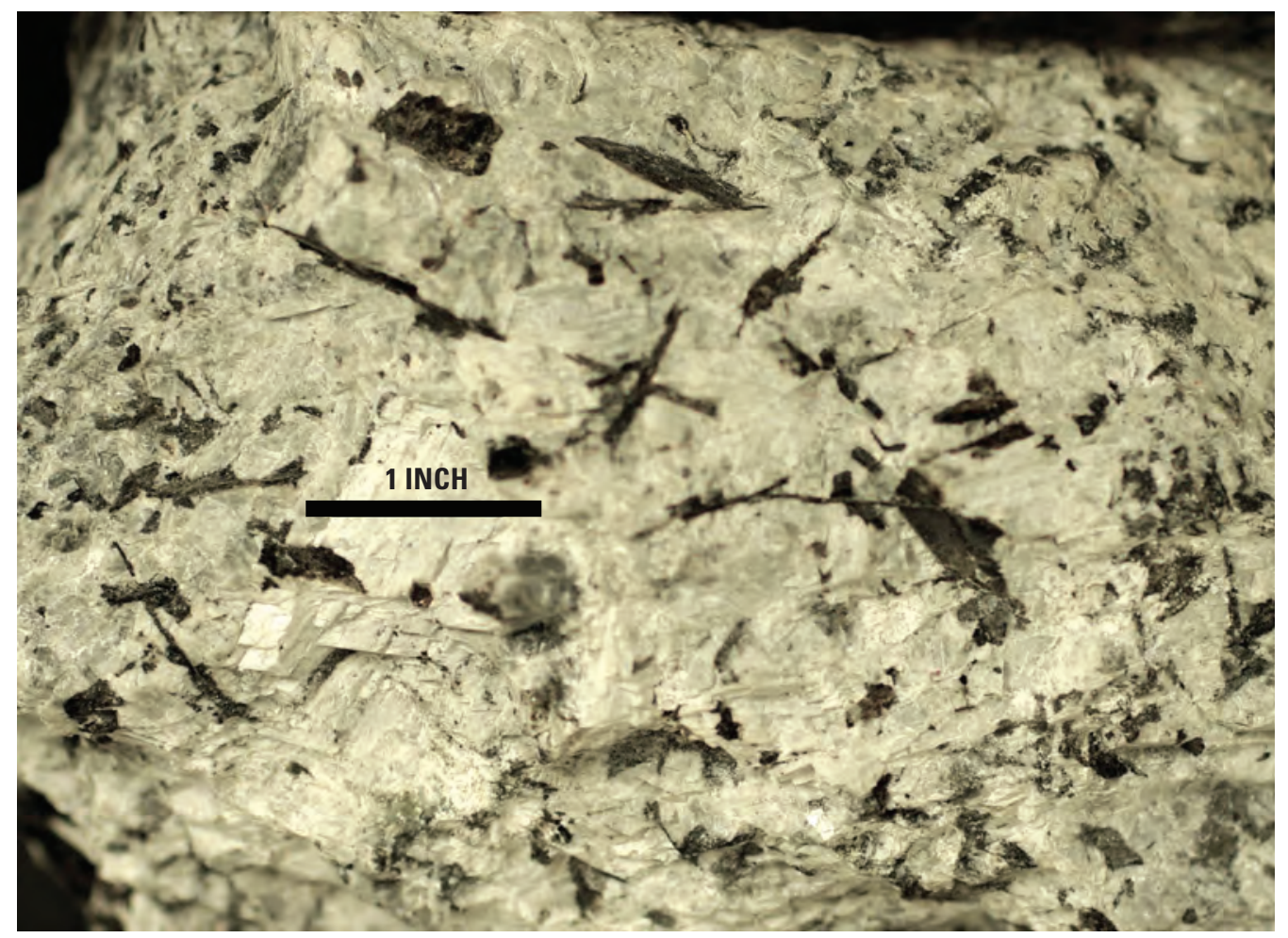

Figure 4. Specimen of nepheline syenite from the Granite Mountain pluton. The principal minerals in this intrusive rock are feldspar (more than half of the rock) and nepheline, with accessory sphene, biotite, pyroxene (diopside and aegirine), sodic amphibole, apatite, magnetite, ilmenite, natrolite, analcime, and sodalite (Gordon and others, 1958).

Table 1. Average concentrations of selected elements in rock samples collected by this study in the Arkansas bauxite region. Analyses for 60 elements for the entire sample set are provided in Van Gosen and Choate (2019).

[Light rare earth elements are shaded gray; heavy rare earth elements are shaded yellow. wt pct, weight percent; ppm, parts per million]

\begin{tabular}{|c|c|c|c|c|c|}
\hline Element & Units & Bauxite $(n=18)$ & Residue $(n=4)$ & Clays $(n=15)$ & Syenite $(\mathrm{n}=16)$ \\
\hline $\mathrm{Al}_{2} \mathrm{O}_{3}$ & wt pct & 47.7 & 9.1 & 29.1 & 19.9 \\
\hline $\mathrm{Ga}$ & $\mathrm{ppm}$ & 76 & 26.4 & 45.6 & 33.3 \\
\hline $\mathrm{Nb}$ & ppm & 662 & 1,075 & 315 & 247 \\
\hline $\mathrm{Sc}$ & ppm & 9 & 10 & 10 & 5 \\
\hline $\mathrm{Ti}$ & wt pct & 1.6 & 1.6 & 0.98 & 0.56 \\
\hline $\mathrm{V}$ & ppm & 186 & 200 & 164 & 45 \\
\hline $\mathrm{La}$ & ppm & 62.5 & 130 & 78.1 & 158 \\
\hline $\mathrm{Ce}$ & ppm & 220 & 382 & 179 & 280 \\
\hline $\operatorname{Pr}$ & ppm & 10 & 21.2 & 11.6 & 27.1 \\
\hline $\mathrm{Nd}$ & ppm & 33.5 & 60.6 & 40.7 & 96 \\
\hline $\mathrm{Sm}$ & ppm & 4.81 & 9.1 & 5.7 & 13.0 \\
\hline $\mathrm{Eu}$ & ppm & 0.69 & 1.32 & 1.13 & 2.36 \\
\hline $\mathrm{Gd}$ & ppm & 4.72 & 9.10 & 5.36 & 10.9 \\
\hline $\mathrm{Tb}$ & ppm & 0.96 & 1.72 & 0.91 & 1.60 \\
\hline Dy & ppm & 6.89 & 12.1 & 5.86 & 8.68 \\
\hline Ho & ppm & 1.57 & 2.90 & 1.24 & 1.64 \\
\hline Er & ppm & 5.96 & 10.2 & 4.37 & 5.15 \\
\hline $\mathrm{Tm}$ & ppm & 1.11 & 1.76 & 0.76 & 0.82 \\
\hline $\mathrm{Yb}$ & ppm & 7.87 & 12.8 & 5.25 & 5.5 \\
\hline $\mathrm{Lu}$ & ppm & 1.18 & 1.92 & 0.80 & 0.82 \\
\hline $\mathrm{Y}$ & ppm & 48.8 & 86.3 & 38.1 & 48.4 \\
\hline
\end{tabular}




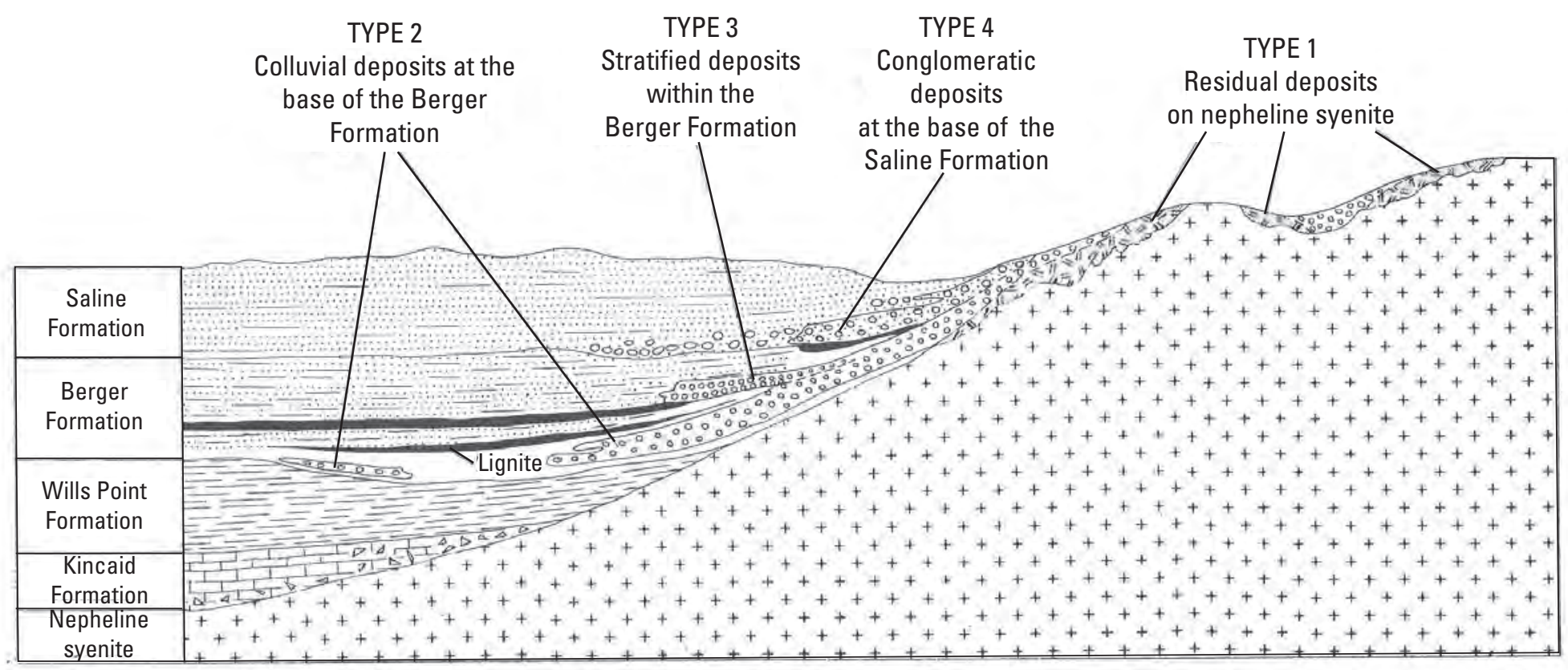

Figure 5. General stratigraphic setting of the bauxite deposit types in the Arkansas bauxite region. Adapted from Gordon and others (1958). 


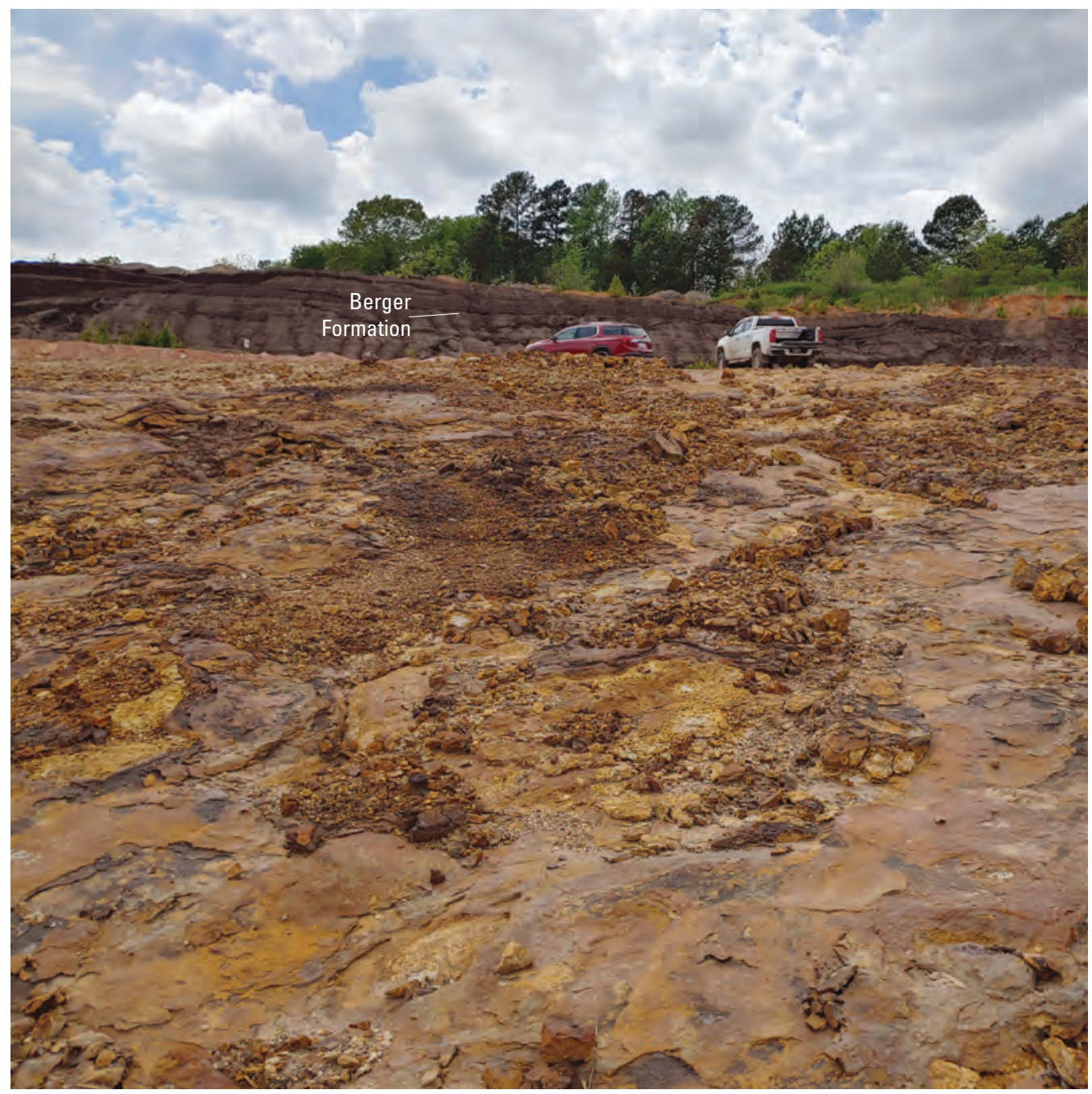

Figure 6. Apron of bauxite layers exposed at the base of a former bauxite mine in central Arkansas (a sample site). The dark brown outcrops above the vehicles are layers of carbonaceous shale and lignite at the base of the overlying Berger Formation of the Wilcox Group that overlies the bauxite (figs. 2 and 5).

\section{Bauxite Ore Processing-Bayer Process}

In addition to the large industry of aluminum recycling, bauxite deposits are the natural source of raw material for producing alumina. From bauxite, aluminum metal is manufactured by the combination of the Bayer process, which produces alumina $\left(\mathrm{Al}_{2} \mathrm{O}_{3}\right)$, and the Hall-Héroult process for smelting alumina (Power and others, 2011). Alumina is produced almost exclusively worldwide using the Bayer process, patented in 1888 by Karl Josef Bayer. Gallium is mainly produced as a byproduct of the Bayer process, and vanadium can be recovered from the sludge (Vind and others, 2018a, 2018b).

The Bayer process takes advantage of the solubility of $\mathrm{Al}^{3+}$ as aluminate- $\mathrm{Al}(\mathrm{OH})_{4}$ - by using concentrated sodium hydroxide (3.6-8.9 moles per liter of a solution), at temperatures of 104-206 degrees Celsius $\left({ }^{\circ} \mathrm{C}\right)$, and pressures of 1.0-6.0 atm, to dissolve aluminum (oxy-) hydroxide minerals in bauxite ore. Due to the low solubility of phyllosilicate clays, a pre-desilication step is often necessary to minimize the silica contamination in the pregnant liquor in order to produce high purity alumina $\left(>98.3\right.$ percent $\mathrm{Al}_{2} \mathrm{O}_{3}$ ) (Gräfe and others, 2011; Vind and others, 2018a, 2018b). Following the bauxite digestion, the pregnant liquor, rich in sodium aluminate$\mathrm{NaAl}(\mathrm{OH})_{4}$ ) - is separated from the remaining solids (bauxite residue and red mud) in pressure decanters or settlers with the aid of flocculants. Other additives may be used to minimize the contamination of the pregnant liquor by soluble and colloidal iron, carbonate, organics (including oxalate), phosphate, and other unwanted impurities (Gräfe and others, 2011).

After separation of the pregnant liquor, the bauxite residue is sequentially washed in counter-current decantation washer trains to recover sodium hydroxide $(\mathrm{NaOH})$ and $\mathrm{NaAl}(\mathrm{OH})_{4}$ 


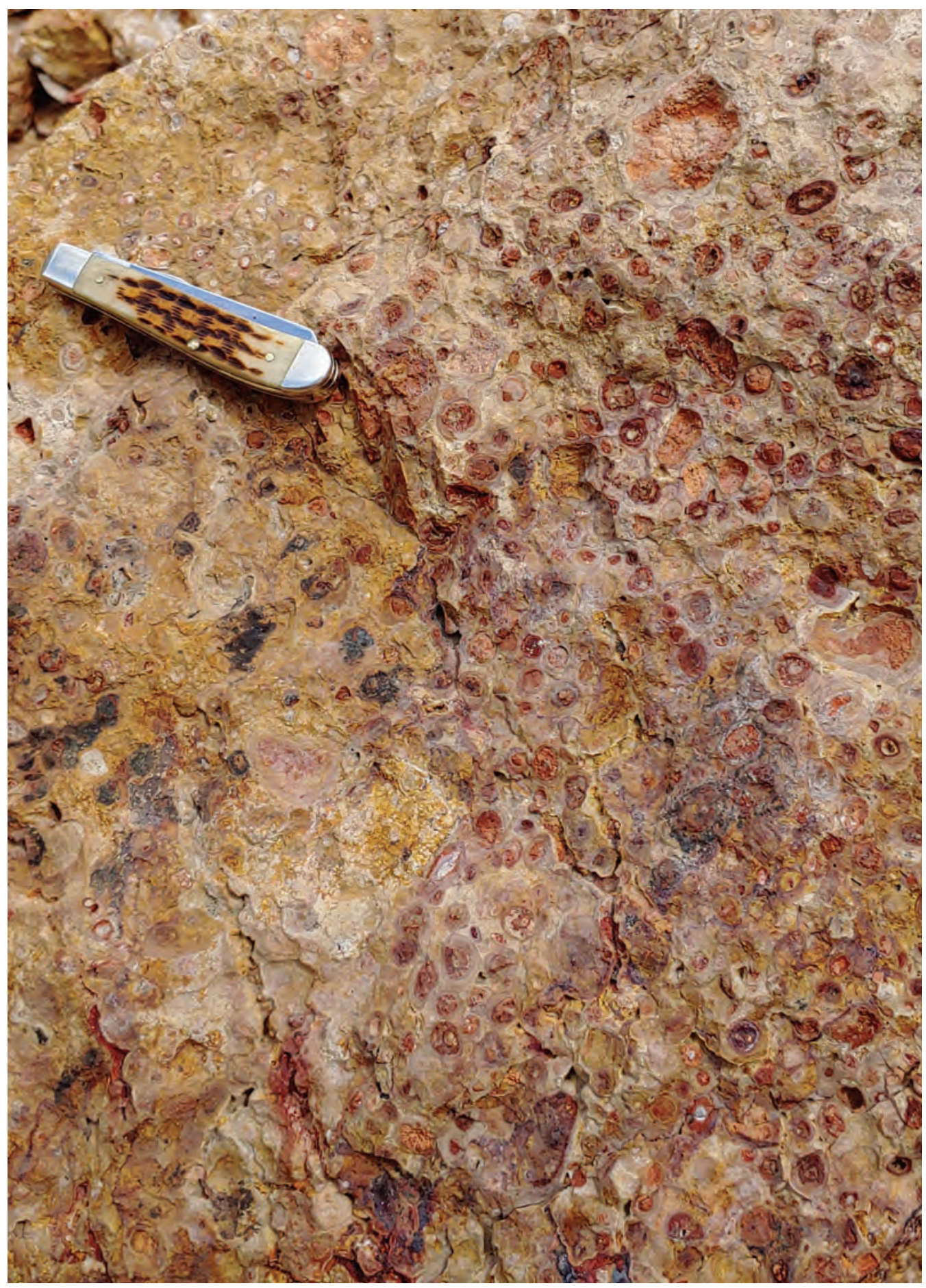

Figure 7. Outcrop of pisolitic bauxite, the most common variety of bauxite in the central Arkansas region.

from the solids and the remaining entrained liquor. The $\mathrm{NaOH}$ and $\mathrm{NaAl}(\mathrm{OH})_{4}$ solution is returned to the Bayer process. The solids (bauxite residue and red mud) are a highly alkaline solid-liquid mixture that is disposed of by one of four methods: lagooning, "dry" stacking, dry cake disposal, or discharge into the ocean (in marine shoreline operations such as in Jamaica) (Gräfe and others, 2011; Power and others, 2011).
$\mathrm{Al}(\mathrm{OH})_{3}$ is precipitated from the sodium-aluminate-rich pregnant liquor by introducing aluminum hydroxide seed crystals. Alumina $\left(\mathrm{Al}_{2} \mathrm{O}_{3}\right)$ is produced by the calcination of the aluminum hydroxide at $>1,000{ }^{\circ} \mathrm{C}$ (Vind and others, 2018a, 2018b). 


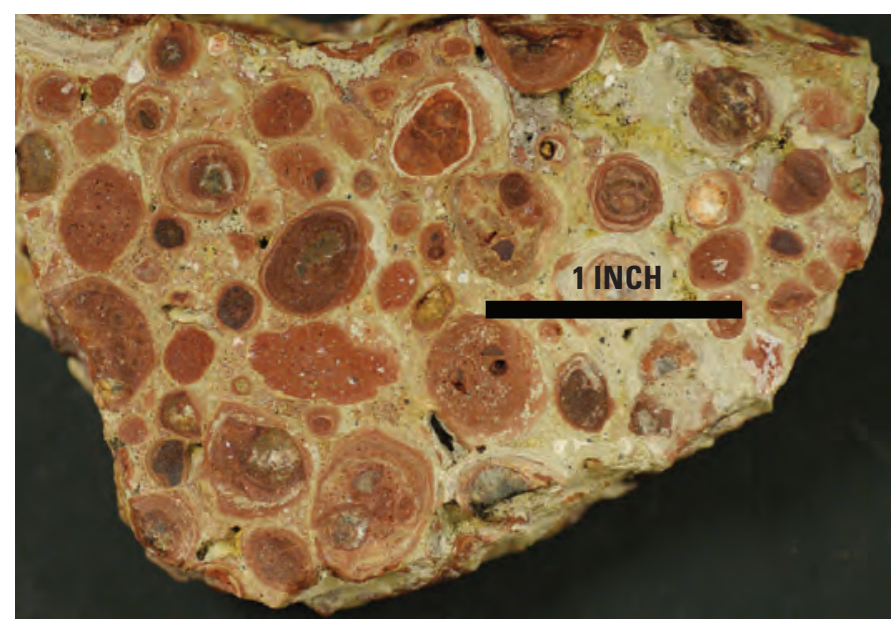

Figure 8. Slabbed specimen of pisolitic bauxite. The spherical concretions are primarily iron-stained gibbsite, with kaolinite in the light-brown matrix between the concretions.

\section{Element Concentrations Relative to Average Upper Crust Abundance}

Figure 9 shows the concentrations of major and trace elements determined from the study samples of bauxite, clays, processing residues, and nepheline syenite relative to their reported average abundance in the Earth's upper crust. Similarly, figure 10 shows the concentrations of the individual REEs in comparison to their average concentrations in the upper crust. The geochemical analyses of the study samples are provided in Van Gosen and Choate (2019). This comparison showed that the bauxite and clays of the district contain concentrations above the upper crustal averages for most of the elements. Elements with much less than crustal concentrations in the bauxite and clays compared with upper crustal averages are barium $(\mathrm{Ba})$, calcium $(\mathrm{Ca})$, cesium $(\mathrm{Cs})$, cobalt $(\mathrm{Co})$, copper $(\mathrm{Cu})$, magnesium $(\mathrm{Mg})$, nickel $(\mathrm{Ni})$, potassium $(\mathrm{K})$, rubidium $(\mathrm{Rb})$, scandium (Sc), silicon (Si), and zinc (Zn) (fig. 9).

Of the elements deemed critical by the USGS in their 2018 analyses (Fortier and others, 2018), three metalsniobium $(\mathrm{Nb})$, titanium (Ti), and zirconium $(\mathrm{Zr})$ - have concentrations in the bauxite, clays, and (or) processing residues that are substantially higher than their average upper crustal abundance and also exceed 500 parts per million (ppm). Each element has values of more than an order of magnitude above their upper crustal averages. While many other metals in the study samples exceed their upper crustal averages, their concentrations do not appear to be economic within the current market conditions for these metals (except for gallium, as discussed in the next section). However, it must be noted that simultaneous byproduct recovery of multiple metals from a processing stream is a technology aspect that is likely to advance significantly in the near future (Nassar and others,
2016). Co-occurring advances will also include multielement recovery from reprocessing previously discarded wastes, such as mill tailings and other processing residues.

Naturally, the bauxite and associated clays are significantly enriched in aluminum (Al), with $\mathrm{Al}$ concentrations of two- to threefold more than its average upper crustal concentration. The relatively high aluminum content (about 20 percent) of the syenites (table 1) accounts for the aluminum ores (bauxites and Al-rich clays) of this district, which formed through intensive weathering and dissolution of the syenites.

\section{Concentrations and Partitioning of Gallium, Niobium, Scandium, and Rare Earth Elements in the Bauxite Deposits}

The metals described in the following sections are highlighted because they are the critical metals that have been considered as potential byproducts of the processing of bauxite to recover alumina in bauxite deposits worldwide.

\section{Gallium}

Gallium is not produced in the United States; the Nation is dependent on imports from France for high-purity galliumbearing materials and on Kazakhstan and Russia for lowpurity materials (Jaskula, 2020). The primary application of gallium is in integrated circuits (semiconductors), followed by uses in optoelectronic devices, such as laser diodes and light-emitting diodes (Jaskula, 2020).

As noted earlier, bauxite is the principal global source of gallium, and gallium is recovered as a byproduct of the processing of bauxite (Schulte and Foley, 2013). This association was predicted in Goldschmidt's classic 1937 paper "The Principles of Distribution of Chemical Elements in Minerals and Rocks," in which he proposed that gallium could be extracted from the alkali aluminate solutions used in the Bayer process (Goldschmidt, 1937). About a decade later, Gordon and Murata (1952) recognized enrichments in gallium in the bauxite ores of central Arkansas. Their samples of bauxite and bauxitic clay found an average gallium content of 0.0086 percent ( $86 \mathrm{ppm}$ ), compared to 0.0020 percent gallium $(20 \mathrm{ppm})$ in the source syenite. Samples from our study in the district found generally similar values, with an average content of $76 \mathrm{ppm}$ gallium in bauxite and $33 \mathrm{ppm}$ gallium in local syenite (table 1).

Except for gallium, most trace elements are enriched in the bauxite sand-clay residue. During the Bayer process, approximately 70 percent of the gallium is dissolved and accumulates in the pregnant liquor or is precipitated with alumina at the end of the process, while 30 percent of the gallium goes into the waste products (Vind and others, 2017, 


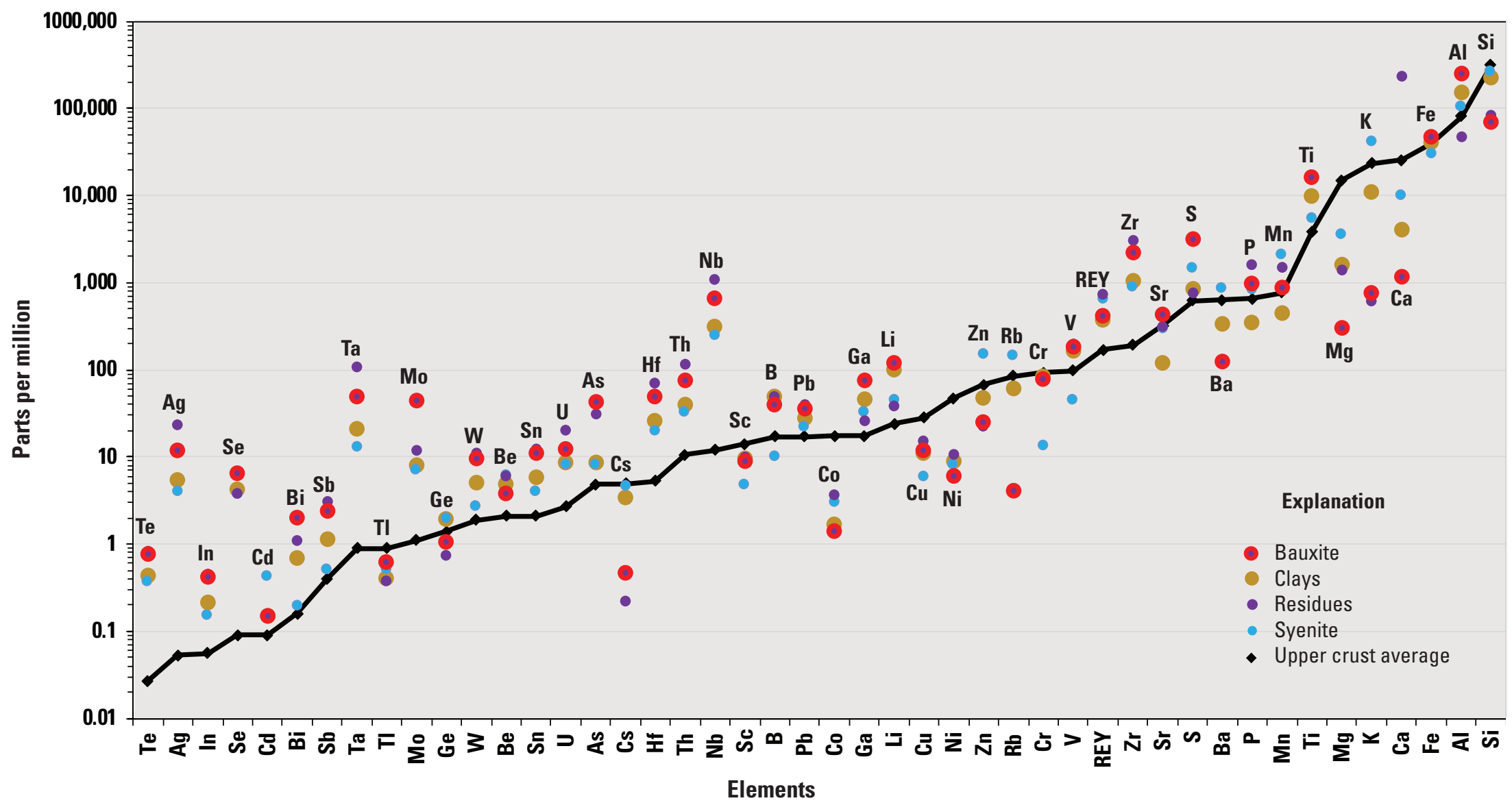

Figure 9. Average concentrations (in parts per million) of elements in the sample types collected in this study in comparison to reported average concentrations in the Earth's upper crust (from Rudnick and Gao, 2003). Tellurium concentration in the upper crust from Hu and Gao (2008). (REY, rare earth elements including yttrium.) 


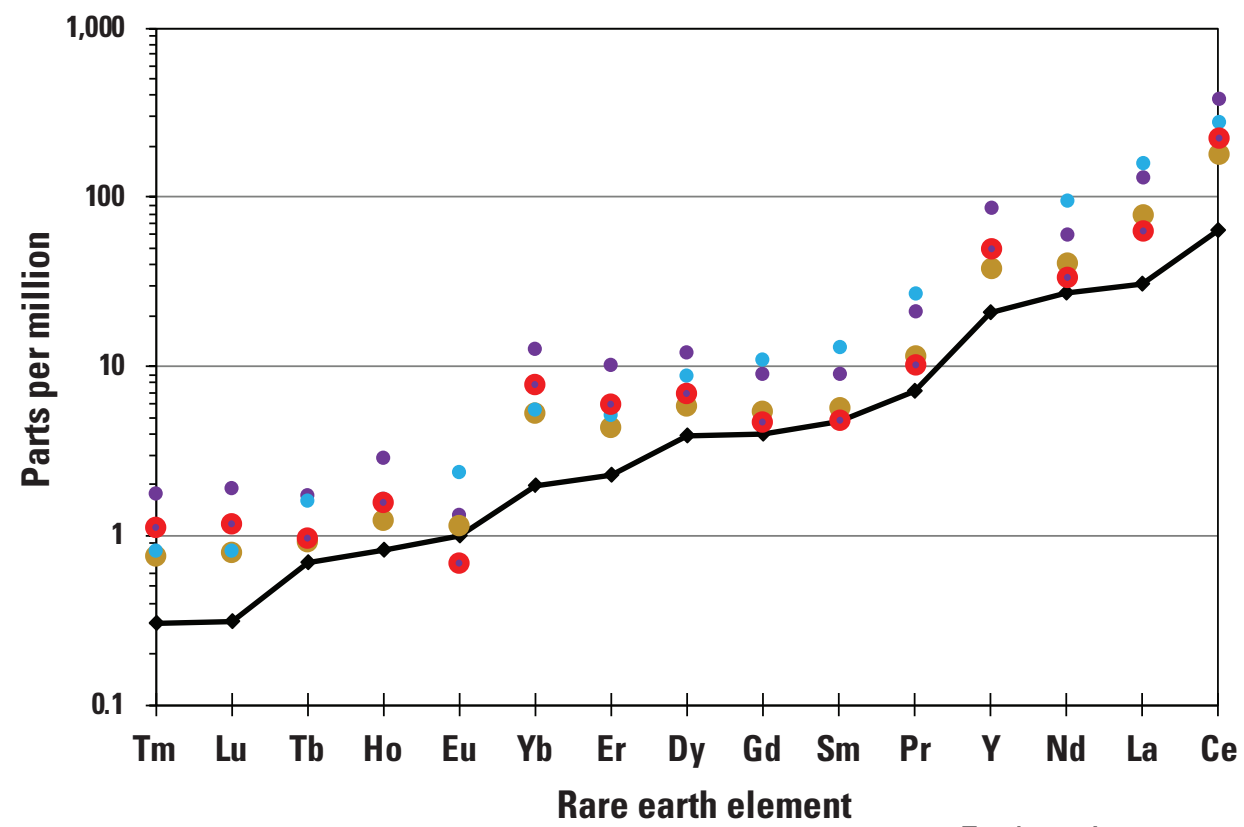

Explanation

- Bauxite

- Clays

- Residues

- Syenite

- Upper crust average

Figure 10. Average concentrations (in parts per million) of the rare earth elements in the sample types collected in this study (table 1) in comparison to their reported average concentrations in the Earth's upper crust (from Rudnick and Gao, 2003).

2018a). The association of gallium with aluminum is evident from our samples of residues, which contain on average only $26 \mathrm{ppm}$ gallium, compared to $76 \mathrm{ppm}$ gallium in raw bauxite. From 1947 to 1983 , gallium was reportedly extracted as a byproduct of processing the bauxite deposits in Saline County (Howard and others, 1997). However, no records of gallium production were published.

\section{Niobium}

Niobium - in the form of ferroniobium - is used mainly as an alloying element in steels and in superalloys. Large quantities of niobium are required for high-purity ferroniobium and nickel niobium that are used in nickel-, cobalt-, and iron-based superalloys, which are important components of jet engines, rocket subassemblies, and heat-resistant and combustion equipment (Padilla, 2020).

A study by the U.S. Bureau of Mines (Nieberlein and others, 1954) investigated metallurgical methods for concentrating and recovering niobium from the bauxites of central Arkansas, and the authors also estimated the columbium resources in the region. (Columbium is a name for niobium used prior to the mid-20th century.) Due to the large resources of bauxite in the region, even with the relatively modest concentrations of niobium (about 0.07 percent niobium in the bauxite by the authors' sampling), Nieberlein and others estimated that potential niobium resources exceeded $78,000,000$ pounds of niobium, due to large bauxite tonnages (Nieberlein and others, 1954). Our reconnaissance sampling found an average of $662 \mathrm{ppm}$ ( 0.066 percent) niobium in samples of bauxite.

Nieberlein and others (1954) concluded that the niobium occurs with ilmenite in the bauxite, which is the primary titanium mineral in the bauxite ores. The niobium (in ilmenite) is concentrated in the waste products of the Bayer alumina production, which are "black sands" and red muds. In the Arkansas bauxite districts, fine-grained black sands were an intermediate product of the Bayer process. These waste product sands are black due to a high content of dark titanium minerals, mainly ilmenite. Because the black sands contain a high content of ilmenite, thus, niobium, within ilmenite, became enriched in the waste residues. As shown in table 1, our samples display a systematic increase in concentration of niobium from parent syenite ( $247 \mathrm{ppm})$ to clays ( $315 \mathrm{ppm})$ and bauxite (662 ppm) and display further enrichment in the processed residues $(1,075 \mathrm{ppm})$. 


\section{Scandium}

The primary uses for scandium in 2018 were in aluminum-scandium alloys and solid oxide fuel cells. Other applications are in ceramics, electronics, lasers, lighting, and radioactive isotopes (Gambogi, 2020b). Scandium has not been mined in the United States for several years. Recently, scandium has been produced as a byproduct from a variety of deposit types in China, Kazakhstan, Russia, and Ukraine. China has been the primary import source for scandium metal and scandium compounds (Gambogi, 2020b). The primary deposits currently used as mined sources of scandium, all recovering scandium as a byproduct, are rare earth elements deposits in carbonatites in China, apatite-rich alkaline intrusions in Russia, and uranium deposits in Ukraine. Also, much of the scandium on the market is recovered from preexisting tailings or waste residues, such as from the uranium districts in Kazakhstan and Russia. During 2018, in the Ural Mountains of Russia, a feasibility study for making scandium oxide as a byproduct of alumina refining was underway. Their pilot plant reportedly produced scandium oxide with purity of greater than 99 percent (Gambogi, 2020b).

Our samples from the Arkansas bauxite district revealed low concentrations of scandium in the parent rock (syenite) and in bauxite, clays, and processing residues. All had average scandium contents of $10 \mathrm{ppm}$ or less. The average crustal abundance of scandium is about $14 \mathrm{ppm}$ (Hu and Gao, 2008). Thus, obtaining scandium as a byproduct from bauxite production from the Arkansas deposits seems unlikely.

\section{Rare Earth Elements}

In the 21 st century, much attention has been drawn to the REEs due to the recognition of their numerous and diverse specialized applications in high-technology devices and components that are imperative to our modern society (Van Gosen and others, 2014, 2019). China has dominated the production and supply of REEs since the late 1990s. Because of the many important uses of REEs, numerous nations and the European Union have voiced concerns over China's expressed intent in recent years to reduce its REE exports. Consequently, global exploration activities to discover or rediscover economic deposits of REEs (or deposits that can provide REEs as byproducts) and then bring them into production have increased (Van Gosen and others, 2017).

For the Arkansas bauxite district, published analyses of the REEs in syenites, bauxites, or processing residues are sparse. This study examined the REE concentrations in the Arkansas bauxites because of their direct association with syenite. Alkaline igneous rocks, including syenites, can be enriched in REEs (Dostal, 2016). For example, the Lovozero deposit (hosted within a nepheline syenite complex in the Kola Peninsula region in far northwestern Russia) has been mined for niobium, and REEs have been recovered as a byproduct (Zaitsev and Kogarko, 2012; Verplanck and others, 2014; Van Gosen and others, 2017). If the syenites of the Arkansas bauxite region were inherently enriched in REEs, these elements could become concentrated by the natural in situ physicochemical processes that formed the clays and bauxite, and the REEs could be further concentrated during alumina processing.

In contrast, this study found modest values for all 15 REEs in samples of bauxite ores, bauxitic clays and interbedded clays, the parent syenite, and the residues from ore processing (table 1, fig. 10) (Van Gosen and Choate, 2019). The analytical results were as follows:

- Bauxite: average of $336 \mathrm{ppm}$ total light REEs, $74 \mathrm{ppm}$ total heavy REEs (includes yttrium);

- Clays: average of 322 ppm total light REEs, 57 ppm total heavy REEs;

- Processing residues (mixture of black sands and red muds): average of 613 ppm total light REEs, $130 \mathrm{ppm}$ total heavy REEs; and

- Source syenites: average of $587 \mathrm{ppm}$ total light REEs, total 73 ppm heavy REEs.

Many of the REE concentrations in the processing residues are higher than in the source syenites (table 1, fig. 10). REEs can be adsorbed on the surface of iron-oxide minerals and clays (Vind and others, 2018b), which become part of the waste residues (red muds) generated by the processing.

Based on the REE concentrations found by this study, the processing residues are unlikely to become economic sources of byproduct REEs. For comparison, clay deposits in southern China have been the predominant global source of the highly sought after heavy REEs for several decades. Described as ion adsorption-type REE deposits, or simply "South China clays," these clays formed by lateritic chemical weathering of biotiteand (or) muscovite-bearing granites (Sanematsu and Watanabe, 2016). Typical REE concentrations in South China clays ores are about $800 \mathrm{ppm}$ total REEs but can be as high as $6,500 \mathrm{ppm}$ total REEs (Sanematsu and Watanabe, 2016). Many of the South China deposits are enriched in the heavy REEs, which are readily extracted from the clays with weak acids.

Broad genetic similarities exist between the South China clay deposits and the bauxite-clay deposits of central Arkansas. The REE-bearing, ion-adsorption clay deposits formed in tropical regions with moderate to high rainfall through the following general process:

1. The REEs are leached by groundwater from granites (the bedrock);

2. Thick zones of laterite soils develop above the granites - this intensely weathered zone contains an abundance of clays; and

3. The mobilized REEs become weakly fixed (ion adsorption) onto the clays (kaolinite and halloysite) in the soils. 
During the early Tertiary, environmental conditions in South China were generally similar to those in Arkansas; that is, tropical conditions caused intense lateritic weathering of the surfaces of the granitic rocks. An important difference in central Arkansas was that the source granitic rocks (nepheline syenites) lacked significant concentrations of REEs upon crystallization (table 1, fig. 10).

\section{Conclusions}

The waste products of processing bauxite to extract alumina, commonly called red muds, have been suggested as potential sources of byproduct gallium $(\mathrm{Ga})$, niobium $(\mathrm{Nb})$, scandium (Sc), rare earth elements (REEs), and other metals in several bauxite deposits worldwide (Liu and Naidu, 2014; Borra and others, 2015; Liu and Li, 2015; Reid and others, 2017). Little published geochemical data exist for the bauxite deposits of central Arkansas (aside from their alumina content), so this reconnaissance study was conducted to fill this data gap. The study sampled and analyzed the parent igneous rocks (syenites), bauxite ore, related clay horizons, and processed mill residues to examine their content of co-occurring metals and to assess their resource potential. The full geochemical analyses and the descriptions of the methods used are available in spreadsheet format in Van Gosen and Choate (2019).

The results of this reconnaissance study suggest that, of the critical minerals of interest, gallium appears to have the most economic potential to be a byproduct of bauxite deposits of central Arkansas. The study found that the highest gallium concentrations occur in the raw bauxite ore (average of 76 parts per million [ppm] bauxite, table 1) and gallium partitions with alumina (the product) rather than into mill waste residues. Gallium was reportedly recovered as a byproduct of bauxite production in the district from 1947 to 1983, but records of this gallium production have not been found (Howard and others, 1997).

Bauxite ore samples examined in this study have an average niobium content of $662 \mathrm{ppm}$ (0.066 percent) (table 1). Our samples show a systematic increase of concentration of niobium from parent syenite (247 ppm Nb) to clays (315 ppm) and bauxite (662 ppm) to processed residues (1,075 ppm) (table 1). Processing wastes informally referred to as black sands are an ilmenite-rich, fine sand-sized intermediate waste product of the Bayer process. Ilmenite grains are the host for niobium in these deposits and, as a result, the black sands have the highest niobium content.

This study found unremarkable concentrations for the light and heavy REEs in samples of bauxite ores, bauxitic clays and interbedded clays, syenite, and the residues of ore processing (table 1) (Van Gosen and Choate, 2019). Our samples from the central Arkansas bauxite deposits have low concentrations of scandium oxide (10 ppm or less) in the parent rock (syenite), bauxite, clays, and processing residues. The highest REE values were in the processing residues, with average concentrations of $613 \mathrm{ppm}$ total light REEs and $130 \mathrm{ppm}$ total heavy REEs. Even if easily extractable from the mill residues, these low REE concentrations suggest that further processing to recover REEs is unlikely to be economic without a substantial increase in the market prices for these elements.

\section{References Cited}

Arkansas Geological Survey, 2019, Bauxite: Little Rock, Ark., Arkansas Geological Survey website, accessed May 20, 2021, at https://www.geology.arkansas.gov/minerals/ industrial/bauxite.html.

Baksi, A.K., 1997, The timing of Late Cretaceous alkalic igneous activity in the northern Gulf of Mexico basin, southeastern USA: The Journal of Geology, v. 105, no. 5, p. 629-644. [Also available at https://doi.org/10.1086/515966.]

Borra, C.R., Pontikes, Y., Binnemans, K., and Van Gerven, T., 2015, Leaching of rare earths from bauxite reside (red mud): Minerals Engineering, v. 76, p. 20-27, accessed May 20, 2021, at https://doi.org/10.1016/j.mineng.2015.01.005.

Bramlette, M.N., 1936, Geology of the Arkansas bauxite region: Arkansas Geological Survey Information Circular 8, 68 p.

Branner, J.C., 1891, Bauxite in Arkansas: American Geologist, v. 12 , p. 181-183.

Branner, J.C., 1897, The bauxite deposits of Arkansas: The Journal of Geology, v. 5, no. 3, p. 263-289.

Bray, E.L., 2018, Bauxite and alumina statistics and information: U.S. Geological Survey National Minerals Information Center, Mineral Commodity Summaries, p. 30-31, accessed May 21, 2021, at https://www.usgs.gov/centers/nmic/ bauxite-and-alumina-statistics-and-information.

Dostal, J., 2016, Rare metal deposits associated with alkaline/ peralkaline igneous rocks, in Verplanck, P.L., and Hitzman, M.W., eds., Rare earth and critical elements in ore deposits: Reviews in Economic Geology, v. 18, p. 33-54, accessed May 20, 2021, at https://doi.org/10.5382/Rev.18.02.

Fortier, S.M., Nassar, N.T., and Lederer, G.W., Brainard, J., Gambogi, J., and McCullough, E.A., 2018, Draft critical mineral list-Summary of methodology and background information-U.S. Geological Survey technical input document in response to Secretarial Order No. 3359: U.S. Geological Survey Open-File Report 2018-1021, 15 p., accessed May 21, 2021, at https://doi.org/10.3133/ ofr20181021.

Frenzel, M., Ketris, M.P., Seifert, T., and Gutzmer, J., 2016, On the current and future availability of gallium: Resources Policy, v. 47, p. 38-50, accessed May 21, 2021, at https://doi.org/10.1016/j.resourpol.2015.11.005. 
Gambogi, J., 2020a, Rare earths statistics and information: U.S. Geological Survey National Minerals Information Center, accessed May 21, 2021, at https://www.usgs.gov/ centers/nmic/rare-earths-statistics-and-information.

Gambogi, J., 2020b, Scandium statistics and information: U.S. Geological Survey National Minerals Information Center accessed May 21, 2021, at https://www.usgs.gov/ centers/nmic/scandium-statistics-and-information?qtscience_support_page_related_con $=0 \# q$ t-science_support page_related_con.

Gibson, C., and Hayes, T., 2011, Indium and gallium overview: Edison Investment Research, Sector Research, 10 p., at https://www.edisoninvestmentresearch.com/sectorreports/ IndiumGalliumOverview071011.pdf.

Goldschmidt, V.M., 1937, The principles of distribution of chemical elements in minerals and rocks - The seventh Hugo Müller Lecture, delivered before the Chemical Society on March 17th, 1937: Journal of the Chemical Society, v. 0, no. 0, p. 655-673. [of London]. [Also available at https://doi.org/10.1039/JR9370000655.]

Gordon, M., Jr., and Murata, K.J., 1952, Minor elements in Arkansas bauxite: Economic Geology and the Bulletin of the Society of Economic Geologists, v. 47, no. 2, p. 169-179. [Also available at https://doi.org/10.2113/ gsecongeo.47.2.169.]

Gordon, M., Jr., Tracey, J.I., Jr., and Ellis, M.W., 1958, Geology of the Arkansas bauxite region: U.S. Geological Survey Professional Paper 299, 268 p., 39 plates. [Also available at https://pubs.usgs.gov/pp/0299/report.pdf.]

Gräfe, M., Power, G., and Klauber, C., 2011, Bauxite residue issues-III. Alkalinity and associated chemistry: Hydrometallurgy, v. 108, no. 1-2, p. 60-79. [Also available at https://doi.org/10.1016/j.hydromet.2011.02.004.]

Hayes, C.W., 1901, The Arkansas bauxite deposits, in Twentyfirst annual report of the United States Geological Survey to the Secretary of the Interior, 1899-1900, Part IIIGeneral Geology, Ore, and Phosphate Deposits Philippines: Washington D.C., Government Printing Office, p. 441-472, at https://pubs.usgs.gov/ar/21-3/report.pdf.

Horton, J.D., 2017, The State Geologic Map Compilation (SGMC) geodatabase of the conterminous United States (ver. 1.1, August 2017): U.S. Geological Survey data release, accessed May 21, 2021, at https://doi.org/10.5066/ F7WH2N65.

Howard, J.M., Colton, G.W., and Prior, W.L., eds., 1997, Mineral, fossil-fuel, and water resources of Arkansas: Arkansas Geological Survey Bulletin 24, 115 p.
Hu, Z., and Gao, S., 2008, Upper crustal abundances of trace elements - A revision and update: Chemical Geology, v. 253 , no. 3-4, p. 205-221.

Jaskula, B.W., 2020, Gallium statistics and information: U.S. Geological Survey National Minerals Information Center, Mineral Commodity Summaries, 2 p., accessed May 21, 2021 at https://www.usgs.gov/centers/nmic/galliumstatistics-and-information.

Liu, Z., and Li, H., 2015, Metallurgical process for valuable elements recovery from red mud-A review: Hydrometallurgy, v. 155, p. 29-43, accessed May 21, 2021, at https://doi.org/10.1016/j.hydromet.2015.03.018.

Liu, Y., and Naidu, R., 2014, Hidden values in bauxite residue (red mud)-Recovery of metals: New York, N.Y., Waste Management, v. 34, no. 12, p. 2662-2673, accessed May 21, 2021, at https://doi.org/10.1016/j.wasman.2014.09.003.

Malamphy, M.C., Dale, G.K., Romslo, T.M., Reed, A.H., Jr., Ollar, A., and Tracey, J.I., Jr., 1948a, Investigation of Arkansas bauxite, volume I: U.S. Bureau of Mines Report of Investigations 4251, 63 p.

Malamphy, M.C., Dale, G.K., Romslo, T.M., Reed, A.H., Jr., Ollar, A., and Tracey, J.I., Jr., 1948b, Investigation of Arkansas bauxite, volume II: U.S. Bureau of Mines Report of Investigations 4252, $16 \mathrm{p}$.

McCullough, E., and Nassar, N.T., 2017, Assessment of critical minerals_-Updated application of an early-warning screening methodology: Mineral Economics, v. 30, no. 3, p. 257-272, accessed May 21, 2021, at https://doi.org/ 10.1007/s13563-017-0119-6.

Mead, W.J., 1915, Occurrence and origin of the bauxite deposits of Arkansas: Economic Geology and the Bulletin of the Society of Economic Geologists, v. 10, no. 1, p. 28-54. [Also available at https://doi.org/10.2113/ gsecongeo.10.1.28.]

Nassar, N.T., Graedel, T.E., and Harper, E.M., 2015, Byproduct metals are technologically essential but have problematic supply: Science Advances, v. 1, no. 3, 10 p., accessed May 21, 2021, at https://doi.org/10.1126/ sciadv. 1400180 .

Nassar, N.T., Wilburn, D.R., and Goonan, T.G., 2016, Byproduct metal requirements for U.S. wind and solar photovoltaic electricity generation up to the year 2040 under various Clean Power Plan scenarios: Applied Energy, v. 183, p. 1209-1226, accessed June 29, 2021, at https://doi.org/10.1016/j.apenergy.2016.08.062.

Nieberlein, V.A., Fine, M.M., Calhoun, W.A., and Parsons, E.W., 1954, Progress report on development of columbium in Arkansas for 1953: U.S. Bureau of Mines Report of Investigations 5064, $23 \mathrm{p}$. 
Padilla, A.J., 2020, Niobium (columbium) and tantalum statistics and information: U.S. Geological Survey National Minerals Information Center, accessed May 21, 2021, at https://www.usgs.gov/centers/nmic/niobium-columbiumand-tantalum-statistics-and-information.

Patterson, S.H., 1967, Bauxite reserves and potential aluminum resources of the World: U.S. Geological Survey Bulletin 1228, 175 p., at https://pubs.usgs.gov/bul/1228/ report.pdf.

Power, G., Gräfe, M., and Klauber, C., 2011, Bauxite residue issues-I. Current management, disposal and storage practices: Hydrometallurgy, v. 108, no. 1-2, p. 33-45. [Also available at https://doi.org/10.1016/j. hydromet.2011.02.006.]

Reid, S., Tam, J., Yang, M., and Azimi, G., 2017, Technospheric mining of rare earth elements from bauxite residue (red mud) - Process optimization, kinetic investigation, and microwave pretreatment: Scientific Reports, v. 7, no. 1, p. 15252, accessed May 21, 2021, at https://doi.org/ 10.1038/s41598-017-15457-8.

Rudnick, R.L., and Gao, S., 2003, 3.01-Composition of the continental crust: Treatise on Geochemistry, v. 3, p. 1-64, accessed May 21, 2021, at https://doi.org/10.1016/B0-08043751-6/03016-4.

Sanematsu, K., and Watanabe, Y., 2016, Characteristics and genesis of ion adsorption-type rare earth element deposits, chap. 3 of Verplanck, P.L., and Hitzman, M.W., eds., Rare earth and critical elements in ore deposits: Reviews in Economic Geology, v. 18, p. 59-79, accessed May 21, 2021, at https://doi.org/10.5382/Rev.18.03.

Schulte, R.F., and Foley, N.K., 2013, Compilation of gallium resource data for bauxite deposits: U.S. Geological Survey Open-File Report 2013-1272, 14 p., 3 separate tables. [Also available at https://pubs.usgs.gov/of/2013/1272/.]

Van Gosen, B.S., and Choate, L.M., 2019, Geochemical analyses of bauxite and associated rocks from the Arkansas bauxite region, central Arkansas: U.S. Geological Survey data release, accessed May 21, 2021, at https://doi.org/ 10.5066/P999FSXM.

Van Gosen, B.S., Verplanck, P.L., and Emsbo, P., 2019, Rare earth element mineral deposits in the United States (ver 1.1, April 15, 2009): U.S. Geological Survey Circular 1454, 16 p., accessed May 21, 2021, at https://doi.org/10.3133/ cir1454.

Van Gosen, B.S., Verplanck, P.L., and Long, K.R., Gambogi, J., and Seal, R.R., II, 2014, The rare-earth elements-Vital to modern technologies and lifestyles: U.S. Geological Survey Fact Sheet 2014-3078, 4 p., accessed May 21, 2021, at https://doi.org/10.3133/fs20143078.
Van Gosen, B.S., Verplanck, P.L., Seal, R.R., II, Long, K.R., and Gambogi, J., 2017, Rare-earth elements, chap. O of Schulz, K.J., DeYoung, J.H., Jr., Seal, R.R., II, and Bradley, D.C., eds., Critical mineral resources of the United StatesEconomic and environmental geology and prospects for future supply: U.S. Geological Survey Professional Paper 1802, p. O1- O31, accessed May 21, 2021, at https://doi.org/10.3133/pp1802O.

Verplanck, P.L., Van Gosen, B.S., Seal, R.R., II, and McCafferty, A.E., 2014, A deposit model for carbonatite and peralkaline intrusion-related rare earth element deposits, chap. J of Mineral deposit models for resource assessment: U.S. Geological Survey Scientific Investigations Report 2010-5070-J, 58 p., accessed May 21, 2021, at https://doi.org/10.3133/sir20105070J.

Vind, J., Alexandri, A., Vassiliadou, V., and Panias, D., 2018a, Distribution of selected trace elements in the Bayer process: Metals, v. 8, no. 5, 21 p., accessed May 21, 2021, at https://doi.org/10.3390/met8050327.

Vind, J., Malfliet, A., Blanpain, B., Tsakiridis, P.E., Tkaczyk, A.H., Vassiliadou, V., and Panias, D., 2018b, Rare earth element phases in bauxite residue: Metals, v. 8, no. 2, 32 p., accessed May 21, 2021, at https://doi.org/10.3390/ $\min 8020077$.

Vind, J., Vassiliadou, V., and Panias, D., 2017, Distribution of trace elements through the Bayer process and its byproducts in the 35th International ICSOBA [International Committee for Study of Bauxite, Alumina \& Aluminium] Conference, Hamburg, Germany, October 5-8, Proceedings: Travaux v. 46, accessed September 2, 2020, at https://pdfs. semanticscholar.org/a26f/30cd3682d2b45cbc4b5b 5608e0a5fa7f3551.pdf.

Zaitsev, V., and Kogarko, L., 2012, Sources and perspectives of REE in the Lovozero massif (Kola Peninsula, Russia): European Mineralogical Conference 2012, v. 1, paper EMC2012-290, accessed September 2, 2020, at https://www.researchgate.net/publication/327347000 Sources_and_perspectives_of_REE_in_the_Lovozero massif_Kola_Peninsula_Russia. 
Publishing support provided by the Science Publishing Network, Denver Publishing Service Center

For more information concerning the research in this report, contact the Center Director, USGS Geology, Geophysics, and Geochemistry Science Center

Box 25046, Mail Stop 973

Denver, CO 80225

(303) 236-1800

Or visit Geology, Geophysics, and Geochemistry Science Center website at https://www.usgs.gov/centers/gggsc 


\section{$\frac{\mathbb{2}}{3}$}

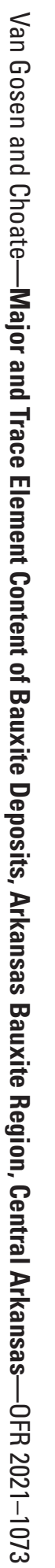

